\title{
IMPROVEMENT OF LISTENING SKILL THROUGH DIRECTED LISTENING THINKING ACTIVITY (DLTA) LEARNING STRATEGY
}

\section{Susanti Fuji Rahayu, Sukarno, Sularmi}

Universitas Sebelas Maret

susan.fujirahayu@gmail.com

\section{Article History}

accepted 09/07/2018

approved 01/08/2018

published 17/09/2018

Keywords

directed listening thinking activity learning strategy, listening skill

\begin{abstract}
The students listening skill are still low. The purpose of this research are: 1) to improve listening skill through DLTA for second grade students of State Primary School Tegalsari Number 60 Surakarta at 2017/2018 academic year, 2) to describe the improvement result listening skill for second grade students of State Primary School Tegalsari Number 60 Surakarta through DLTA learning strategy. The data collecting techniques used are observation, interview, documentation, and test. The data validity test use triangulation of sources and technique and content of validity. The data analysis techniques is interactive analysis model. The clasical mastery criteria for pre-cycle is up to $26,09 \%$ from 23 students achieved the minimal competences criteria (70). At the first cycle, the clasical mastery up 56,52\% and at the second cycle up to $91,30 \%$. Based on this research we can conclude that application Directed Listening Thinking Activity (DLTA) learning strategy can improve listening skill.
\end{abstract}

Social, Humanities, and Education Studies (SHEs): Conference Series https://jurnal.uns.ac.id/shes
p-ISSN 2620-9284

e-ISSN 2620-9292 


\section{PENDAHULUAN}

Kehidupan sehari-hari manusia tidak terlepas dari komunikasi dengan orang lain. Dalam berkomunikasi seseorang perlu memiliki keterampilan menyimak. Bahasa Indonesia merupakan pelajaran yang membelajarkan siswa untuk berkomunikasi dengan baik dan benar melalui keterampilan berbahasa. Namun kenyataannya, pembelajaran keterampilan berbahasa belum dilakukan secara maksimal. Jika keterampilan berbahasa diharapkan untuk dikuasai peserta didik, maka pembelajaran yang dilakukan dengan metode ceramah sulit untuk meningkatkan keterampilan berbahasa siswa karena metode ceramah membosankan bagi peserta didik dan sulit untuk dipahami.

Menyimak termasuk aktivitas penting dalam pembelajaran bahasa. Gulec dan Durmus (2015) mengungkapkan bahwa menyimak adalah aktivitas mental yang disadari untuk memahami apa yang didengar. Melalui menyimak, seseorang mampu mendengarkan suatu informasi dengan memahami informasi tersebut secara baik. Adapun Saddhono dan Slamet (2014) berpendapat bahwa keterampilan menyimak merupakan aktivitas yang paling awal dilakukan oleh manusia bila dilihat dari proses pemerolehan keterampilan berbahasa. Dengan demikian keterampilan menyimak memengaruhi keterampilan berbahasa lainnya yaitu keterampilan berbicara, membaca, dan menulis. Logan, et al mengungkapkan bahwa tahap menyimak terdiri dari 5 tahapan, yaitu: 1) tahap mendengarkan, 2) tahap memahami, 3) tahap mengiterpretasi, 4) tahap mengevaluasi, dan 5) tahap menanggapi (Tarigan, 2008). Keterampilan menyimak siswa Sekolah Dasar antar kelas tidak sama. Anderson berpendapat bahwa kemampuan menyimak siswa kelas II sekolah dasar yang biasanya berusia $6 \frac{1 / 2}{2} 8$ tahun antara lain: 1) menyimak dengan kemampuan memilih yang meningkat, 2) membuat saran-saran, usul-usul, dan pertanyaan-pertanyaan untuk mengecek pengertiannya, dan 3) sadar akan situasi, kapan sebaiknya menyimak, kapan juga sebaiknya tidak perlu menyimak (Tarigan, 2008).

Tentu sulit jika mengajarkan keterampilan menyimak hanya menggunakan metode ceramah karena materi yang disampaikan akan terasa membosankan dan sulit dipahami. Metode ceramah membiasakan siswa menjadi pasif pada pembelajaran yang berlangsung. Pembelajaran bahasa terutama mengenai keterampilan menyimak harus dirancang menjadi pembelajaran yang menyenangkan dan tidak membosankan. Dengan demikian pembelajaran akan menjadi lebih efektif dan menarik sehingga peserta didik memperhatikan ketika pembelajaran. Jika pembelajaran menyimak tidak dikelola dengan baik akan menyebabkan rendahnya keterampilan berbahasa lainnya. Hasil observasi awal penelitian menunjukkan bahwa dari 23 siswa hanya 6 siswa atau 26,1\% yang mendapatkan nilai di atas kriteria ketuntasan minimal yang telah ditetapkan yaitu 70 , sedangkan 17 lainnya atau $73,9 \%$ mendapat nilai di bawah KKM. Rata-rata nilai keterampilan menyimak yaitu 46,43. Hal ini menunjukkan bahwa keterampilan menyimak siswa masih rendah.

Berdasarkan permasalahan tersebut, diperlukan usaha guru untuk memperbaiki proses pembelajaran Bahasa Indonesia mengenai keterampilan menyimak siswa. Apabila permasalahan tidak segera diatasi maka siswa akan cenderung mengalami kesulitan dalam menyimak. Siswa sulit menemukan pokok-pokok cerita yang disampaikan dalam cerita atau pesan pendek. Usaha perbaikan pembelajaran tersebut dapat dilakukan dengan penerapan strategi pembelajaran yang inovatif. Dari berbagai macam strategi pembelajaran, salah satu strategi pembelajaran yang dapat menjadi alternatif perbaikan keterampilan menyimak siswa adalah strategi pembelajaran Directed Listening Thinking Activity (DLTA).

Strategi Directed Listening Thinking Activity (DLTA) merupakan salah satu strategi pembelajaran menyimak yang mengikutsertakan siswa dalam pembelajaran. Barone menyatakan bahwa strategi Directed Listening Thinking Activity (DLTA) adalah strategi yang dapat digunakan untuk mengajarkan pemahaman saat membaca dengan keras pada siswa (Wibowo, 2016). Hal ini diterapkan ketika siswa mendengarkan topik 
apa yang dibaca oleh guru, sehingga siswa diharapkan lebih mampu memahami simakan yang didengarnya. Langkah-langkah pembelajaran DLTA menurut Abidin (2012) yaitu: (a) tahap prasimak yang berisi perkenalan materi simakan dan pembuatan prediksi, (b) tahap menyimak yang berisi kegiatan menyimak dan menguji prediksi serta (c) tahap pascasimak yang melatih keterampilan kreatif. Strategi pembelajaran ini melatih pendengaran dan keterlibatan siswa dalam berpikir tentang bacaan, melatih siswa dalam menguji prediksi dan melatih keterampilan kreatif siswa.

Kelebihan strategi DLTA adalah sebagai berikut: 1) strategi DLTA meningkatkan kemampuan siswa dalam memprediksi cerita sehingga membantu dalam memperoleh gambaran keseluruhan cerita, 2) strategi ini mengembangkan kemampuan bertanya siswa, 3) strategi ini melatih kemampuan menganalisis siswa, 4) strategi DLTA lebih menarik perhatian siswa karena pembelajarannya menyenangkan, 5) strategi DLTA menjadikan pembelajaran menjadi lebih interaktif. Pembelajaran yang menyenangkan lebih mudah dipahami oleh siswa. Dengan demikian diharapkan melalui penerapan strategi DLTA dapat mebuat siswa aktif dalam pembelajaran dan meningkatkan hasil keterampilan menyimak siswa.

Berdasarkan uraian tersebut, peneliti melakukan penelitian dengan judul "Peningkatan Keterampilan Menyimak Melalui Penerapan Strategi Pembelajaran Directed Listening Thinking Activity (DLTA) (Penelitian Tindakan Kelas pada Siswa Kelas II SD Negeri Tegalsari No. 60 Surakarta Tahun Ajaran 2017/ 2018)". Peneliti juga menyusun rumusan masalah penelitian yaitu: 1) "Apakah penerapan strategi pembelajaran Directed Listening Thinking Activity (DLTA) dapat meningkatkan keterampilan menyimak pada siswa kelas II SD Negeri Tegalsari No. 60 Surakarta Tahun Ajaran 2017/ 2018?" 2) "Bagaimanakah hasil peningkatan keterampilan menyimak siswa kelas II SD Negeri Tegalsari No. 60 Surakarta melalui penerapan strategi pembelajaran Directed Listening Thinking Activity (DLTA)?" Sesuai dengan rumusan masalah tersebut, penelitian ini bertujuan: 1) untuk meningkatkan keterampilan menyimak melalui penerapan strategi pembelajaran Directed Listening Thinking Activity (DLTA) pada siswa kelas II SD Negeri Tegalsari No. 60 Surakarta Tahun Ajaran 2017/2018, 2) untuk mendeskripsikan hasil peningkatan keterampilan menyimak siswa kelas II SD Negeri Tegalsari No. 60 Surakarta melalui penerapan strategi pembelajaran Directed Listening Thinking Activity (DLTA).

\section{METODE}

Penelitian ini merupakan Penelitian Tindakan Kelas (PTK) yang dilakukan di SD Negeri Tegalsari No. 60 Surakarta pada bulan Desember-Juni 2018. Subjek penelitian ini adalah siswa kelas II. Jumlah siswa kelas II adalah 23 siswa yang terdiri dari 9 siswa laki-laki dan 14 siswa perempuan. Di kelas tersebut tidak ada siswa yang termasuk dalam kategori anak yang berkebutuhan khusus.

Teknik pengumpulan data yaitu melalui observasi, wawancara, dokumentasi, dan tes. Uji validitas data menggunakan triangulasi sumber, triangulasi teknik, dan validitas isi. Teknik analisis data menggunakan model interaktif Miles dan Huberman (2014) yang terdiri dari tiga tahap, yaitu reduksi data, penyajian data, dan penarikan kesimpulan.

Tes keterampilan menyimak menurut Nurgiyantoro (2016) dapat dilakukan dengan tes tradisional maupun tes otentik. Tes tradisional menuntut peserta didik untuk mengidentifikasi atau merespon jawaban yang telah disediakan seperti pilihan ganda. Sedangkan tes otentik menuntut siswa untuk mengkonstruksi jawaban sendiri baik lisan, tertulis, ataupun keduanya. Penilaian kinerja pemahaman menyimak dibagi menjadi dua yaitu secara lisan dan tertulis. 


\section{HASIL DAN PEMBAHASAN}

Penelitian ini dilakukan selama 2 siklus. Masing-masing siklus terdiri dari 2 kali pertemuan. Setiap pertemuan memiliki alokasi waktu 2x35 menit. Materi menyimak pada siklus I adalah cerita pesan pendek, sedangkan pada siklus II menggunakan materi dongeng. Berdasarkan hasil penelitian, keterampilan menyimak siswa mengalami peningkatan mulai dari pratindakan, siklus I, dan siklus II. Hal ini dapat dilihat dari ketuntasan klasikal dan rata-rata nilai keterampilan menyimak. Pada kondisi awal keterampilan menyimak siswa masih rendah. Berikut ini, disajikan tabel 1 hasil pratindakan keterampilan menyimak sebelum dilakukan tindakan.

Tabel 1. Distribusi Frekuensi Nilai Keterampilan Menyimak Pratindakan

\begin{tabular}{|c|c|c|c|c|c|c|}
\hline \multirow[b]{2}{*}{ No } & \multirow{2}{*}{$\begin{array}{c}\text { Interval } \\
\text { Nilai }\end{array}$} & \multirow{2}{*}{$\begin{array}{l}\text { Frekuensi } \\
\text { (f) }\end{array}$} & \multirow{2}{*}{$\begin{array}{c}\text { Nilai } \\
\text { Tengah } \\
\text { (xi) }\end{array}$} & \multicolumn{2}{|c|}{ Persentase } & \multirow[b]{2}{*}{ Keterangan } \\
\hline & & & & Relatif & Kumulatif & \\
\hline 1. & $11-22$ & 1 & 16,5 & 4,35 & 4,35 & Belum Tuntas \\
\hline 2. & $23-34$ & 5 & 28.5 & 21.74 & 26.09 & Belum Tuntas \\
\hline 3. & $35-46$ & 8 & 40,5 & 34,78 & 60,87 & Belum Tuntas \\
\hline 4. & $47-58$ & 3 & 52,5 & 13,04 & 73.91 & Belum Tuntas \\
\hline 5. & $59-70$ & 0 & 64,5 & 0 & 73.91 & Belum Tuntas \\
\hline 6. & $\begin{array}{l}71-82 \\
\text { Jumlah }\end{array}$ & $\begin{array}{c}6 \\
23\end{array}$ & 76,5 & $\begin{array}{c}26,09 \\
100\end{array}$ & 100 & Tuntas \\
\hline \multicolumn{3}{|c|}{$\begin{array}{c}\text { Nilai Rata-rata } \\
\text { Ketuntasan Klasikal }\end{array}$} & & & & $\begin{array}{r}46,43 \\
26,09 \%\end{array}$ \\
\hline \multicolumn{3}{|c|}{ Nilai Terendah } & & & & $\begin{array}{l}12 \\
79\end{array}$ \\
\hline
\end{tabular}

Berdasarkan tabel 1 dapat diketahui bahwa siswa yang memperoleh nilai pada interval $11-22$ terdapat 1 siswa atau sebesar $4,35 \%$. Siswa yang memperoleh nilai pada interval 23 - 34 sebanyak 5 siswa atau sebesar $21,74 \%$. Siswa yang memperoleh nilai pada interval $35-46$ sebanyak 8 siswa atau sebesar $34,78 \%$. Siswa yang memperoleh nilai pada interval 47 - 58 sebanyak 3 siswa atau sebesar $13,04 \%$. Tidak ada siswa yang memperoleh nilai pada interval 59 - 70, sedangkan siswa yang memperoleh nilai pada interval nilai 71 - 82 sebanyak 6 siswa atau sebesar $26,09 \%$. Dari 23 siswa, terdapat 6 siswa atau sebesar 26,09\% siswa yang tuntas dengan nilai di atas KKM (70). Siswa yang belum tuntas pada tes pratindakan sebanyak 17 siswa atau sebesar $73,91 \%$ dengan nilai di bawah KKM (70). Nilai tertinggi mencapai 79, sedangkan nilai terendah siswa adalah 12 dan rata-rata nilai yaitu 46,63. Hal tersebut, menunjukkan bahwa keterampilan menyimak siswa kelas II SD Negeri Tegalsari No. 60 Surakarta masih rendah. Hal ini disebabkan karena siswa kurang tertarik dengan pembelajaran menyimak yang berlangsung. Kebanyakan siswa merasa bosan saat pembelajaran. Siswa belum aktif dalam pembelajaran keterampilan menyimak.

Solusi untuk mengatasi permasalahan tersebut adalah memberikan suatu variasi strategi pembelajaran. Salah satunya yaitu penggunaan strategi pembelajaran yang inovatif. Strategi pembelajaran inovatif ini dapat berupa strategi pembelajaran Directed Listening Thinking Activity (DLTA). Strategi pembelajaran DLTA dapat meningkatkan keterampilan menyimak siswa. Berdasarkan data tersebut, dilaksanakan tindakan kelas untuk meningkatkan keterampilan menyimak siswa. Perolehan nilai keterampilan menyimak setelah dilakukan tindakan mengalami peningkatan. Hal tersebut, dapat dilihat mulai dari siklus I. Nilai keterampilan menyimak pada siklus I diperoleh dari ratarata nilai keterampilan menyimak pertemuan 1 dan pertemuan 2. Hasil nilai keseluruhan pada siklus I dapat dilihat pada tabel 2. 
Tabel 2. Distribusi Frekuensi Nilai Keterampilan Menyimak Siklus I

\begin{tabular}{|c|c|c|c|c|c|c|}
\hline \multirow[b]{2}{*}{ No. } & \multirow{2}{*}{$\begin{array}{c}\text { Interval } \\
\text { Nilai }\end{array}$} & \multirow{2}{*}{$\begin{array}{l}\text { Frekuensi } \\
\text { (f) }\end{array}$} & \multirow{2}{*}{$\begin{array}{c}\text { Nilai } \\
\text { Tengah } \\
\text { (xi) }\end{array}$} & \multicolumn{2}{|c|}{ Persentase } & \multirow[b]{2}{*}{ Keterangan } \\
\hline & & & & Relatif & Kumulatif & \\
\hline 1. & $46-51$ & 5 & 48,5 & 21,73 & 21,73 & Belum tuntas \\
\hline 2. & $52-57$ & 2 & 54,5 & 8,7 & 30,43 & Belum tuntas \\
\hline 3. & $58-63$ & 2 & 60,5 & 8,7 & 39,13 & Belum tuntas \\
\hline 4. & $64-69$ & 1 & 66,5 & 4,35 & 43,48 & Belum tuntas \\
\hline 5. & $70-75$ & 9 & 72,5 & 39,13 & 82,61 & Tuntas \\
\hline 6. & $76-81$ & 4 & 78,5 & 17,39 & 100 & Tuntas \\
\hline \multirow[t]{4}{*}{ Jumla } & & 23 & & 100 & & \\
\hline & $\begin{array}{r}\text { Nile } \\
\text { Ketun }\end{array}$ & $\begin{array}{l}\text { Rata-rata } \\
\text { Isan Klasika }\end{array}$ & & & & $\begin{array}{r}64,74 \\
56,52 \%\end{array}$ \\
\hline & Nila & Terendah & & & & 47 \\
\hline & Nile & i Tertinggi & & & & 79 \\
\hline
\end{tabular}

Berdasarkan tabel 2. dapat dilihat bahwa 13 siswa sudah tuntas atau nilainya sudah mencapai KKM yaitu 70. Nilai rata-rata kelas pada siklus I mencapai 64,74. Persentase ketuntasan klasikal sebesar $56,52 \%$. Nilai tertinggi yang diperoleh adalah 79. Nilai terendah yang diperoleh adalah 47. Pada siklus I masih terdapat 10 siswa yang belum tuntas nilai keterampilan menyimaknya. Siswa tersebut terdapat pada rentang nilai 46 - 51 yaitu sebanyak 5 siswa, nilai 52 - 57 sebanyak 2 siswa, nilai 58 63 sebanyak 2 siswa, dan nilai 64 - 69 sebanyak 1 siswa. Nilai tertinggi pada siklus I yaitu 79 dan nilai terendah 47 . Hasil tersebut menunjukan bahwa ketuntasan klasikal sudah mengalami peningkatan akan tetapi belum mencapai $80 \%$.

Perolehan nilai kemampuan pemecahan masalah setelah dilakukan tindakan kelas selanjutnya mengalami peningkatan dari siklus I. Berikut ini disajikan hasil nilai keseluruhan pada siklus II dapat dilihat pada tabel 3.

Tabel 3. Distribusi Frekuensi Nilai Keterampilan Menyimak Siklus II

\begin{tabular}{|c|c|c|c|c|c|c|}
\hline \multirow[b]{2}{*}{ No. } & \multirow{2}{*}{$\begin{array}{c}\text { Interval } \\
\text { Nilai }\end{array}$} & \multirow{2}{*}{$\begin{array}{l}\text { Frekuensi } \\
\text { (f) }\end{array}$} & \multirow{2}{*}{$\begin{array}{c}\text { Nilai } \\
\text { Tengah } \\
\text { (xi) }\end{array}$} & \multicolumn{2}{|c|}{ Presentase } & \multirow[b]{2}{*}{ Keterangan } \\
\hline & & & & Relatif & Kumulatif & \\
\hline 1. & $52-57$ & 1 & 54,5 & 4,35 & 4,35 & Belum tuntas \\
\hline 2. & $58-63$ & 0 & 60,5 & 0 & 4,35 & Belum tuntas \\
\hline 3. & $64-69$ & 1 & 66,5 & 4,35 & 8,7 & Belum tuntas \\
\hline 4. & $70-75$ & 8 & 72,5 & 34,77 & 43,47 & Tuntas \\
\hline 5. & $76-81$ & 6 & 78,5 & 26,09 & 69,56 & Tuntas \\
\hline 6. & $82-87$ & 6 & 84,5 & 26,09 & 95,65 & Tuntas \\
\hline 7. & $88-93$ & 1 & 90,5 & 4,35 & 100 & Tuntas \\
\hline \multirow[t]{4}{*}{ Jumlar } & lh & 23 & & 100 & & \\
\hline & $\begin{array}{r}\text { Nilk } \\
\text { Ketun }\end{array}$ & $\begin{array}{l}\text { Rata-rata } \\
\text { san Klasikal }\end{array}$ & & & & $\begin{array}{r}77,39 \\
91,30 \%\end{array}$ \\
\hline & Nila & Terendah & & & & 56 \\
\hline & Nil & Tertinggi & & & & 91 \\
\hline
\end{tabular}

Berdasarkan tabel 3. dapat dilihat bahwa 21 siswa sudah tuntas atau nilainya sudah mencapai KKM yaitu 70 . Nilai rata-rata kelas pada siklus II mencapai 77,39. Persentase ketuntasan klasikal sebesar $91,30 \%$. Nilai tertinggi yang diperoleh adalah 91. Nilai terendah yang diperoleh adalah 56. Pada siklus II hanya terdapat 2 siswa yang belum tuntas nilai keterampilan menyimaknya. Siswa tersebut terdapat pada rentang nilai 52 - 57 yaitu sebanyak 1 siswa dan pada rentang nilai 64 - 69 sebanyak 1 siswa. 
Setelah dilakukan penelitian sesuai dengan yang telah dipaparkan diatas, maka dapat disimpulkan bahwa strategi pembelajaran Directed Listening Thinking Activity (DLTA) dapat meningkatkan keterampilan menyimak siswa kelas II SD Negeri Tegalsari No. 60 Surakarta. Ketuntasan Kriteria Minimal yaitu $\geq 70$ atau kategori terampil dapat dijadikan patokan untuk melihat peningkatan keterampilan menyimak. Peningkatan keterampilan menyimak juga dapat dilihat dari skor rata-rata yang dari hasil pratindakan sebesar 46,43 atau belum mencapai nilai KKM, siklus I sebesar 64,74 atau belum mencapai nilai KKM, dan siklus II sebesar 77,39 atau sudah mencapai nilai KKM. Selain itu, peningkatan keterampilan menyimak dapat dilihat dari ketuntasan mulai dari pratindakan sebesar $26,09 \%$, siklus I $56,52 \%$, dan siklus II $91,30 \%$.

Berdasarkan uraian tersebut, dapat diketahui bahwa pada awal kegiatan sebelum menerapkan strategi pembelajaran Directed Listening Thinking Activity (DLTA) keterampilan menyimak siswa masih rendah dan rata-rata siswa mendapat nilai dibawah KKM. Selanjutnya, setelah menerapkan strategi pembelajaran DLTA keterampilan menyimak siswa mengalami peningkatan. Peningkatan keterampilan menyimak disebabkan karena penerapan strategi DLTA. Strategi DLTA membuat siswa senang dan tertarik terhadap pembelajaran. Hal ini sesuai dengan pendapat AlKhayyat (2015: 55) bahwa DLTA membantu siswa memahami teks dengan cara yang menyenangkan. Hal tersebut menjadi salah satu kelebihan dari strategi DLTA. Penerapan strategi DLTA membuat siswa lebih memahami bahan simakan. Hal ini dikarenakan siswa tertarik mengikuti pembelajaran yang membuat siswa ikut berpikir kreatif pada pembelajaran sehingga lebih memahami bahan simakan.

Hasil penelitian ini sesuai dengan hasil penelitian yang dilakukan oleh Riga Zahara Nurani (2017) yaitu pengaruh strategi Directed Listening Thinking Activity (DLTA) berbantuan media audio visual terhadap kemampuan menyimak dongeng siswa kelas V SD. Rata-rata kemampuan menyimak dongeng kelas eksperimen sebelum diberi tindakan sebesar 67,20 dan setelah diberi tindakan menjadi 84,53. Adapun rata-rata kemampuan menyimak dongeng kelas kontrol sebelum diberi tindakan sebesar 67,26 dan setelah diberi tindakan menjadi 77,55. Hal tersebut membuktikan bahwa strategi Directed Listening Thinking Activity (DLTA) berpengaruh positif pada kemampuan menyimak dongeng.

Dalam penerapan strategi DLTA juga memiliki beberapa kendala yaitu beberapa siswa mengalami kesulitan dalam membuat prediksi. Agar pembelajaran yang berlangsung lebih berkualitas, maka kelemahan yang ada pada strategi DLTA perlu diatasi. Beberapa cara untuk mengatasi kelemahan tersebut adalah guru membantu siswa untuk membuat prediksi. Selain itu guru perlu memberikan materi pembelajaran terlebih dahulu mengenai hal-hal yang bersangkutan dengan materi simakan.

\section{SIMPULAN}

Berdasarkan hasil analisis data dan pembahasan maka disimpulkan bahwa penerapan strategi pembelajaran DLTA dapat meningkatkan keterampilan menyimak siswa kelas II SD Negeri Tegalsari No. 60 Surakarta tahun ajaran 2017/2018. Implikasi dari penelitian ini adalah dapat dijadikan salah satu strategi untuk meningkatkan keterampilan menyimak Penelitian ini dapat menjadi gambaran bagi guru mengenai langkah pembelajaran dalam penerapan strategi Directed Listening Thinking Activity (DLTA). Adanya penelitian ini diharapkan bagi peneliti selanjutnya yang akan melaksanakan penelitian sama mengenai Directed Listening Thinking Activity (DLTA) hendaknya melakukan kajian teori lebih mendalam guna memperbaiki kekurangan dalam penelitian ini. 


\section{DAFTAR PUSTAKA}

Abidin, Y. (2012). Pembelajaran Bahasa Berbasis Pendidikan Karakter. Bandung: PT. Refika Aditama.

Al-Khayyat, A.S.J. (2015). The Impact of Directed Listenig Thinking Activity (DLTA) on Developing University Students' Listening Competencies. International Journal of English and Education ISSN: 2278-4012 Vol. 4 Issue 4 Oktober 2015. Diakses tanggal $14 \quad$ Desember 2017 dari http://ijee.org/yahoo_site_admin/assets/docs/5.271153701.pdf.

Gulec, S. \& Nazli D. (2015). A Study To Develop Listening Skills Of Elementary Second Grade Students. Procedia - Social and Behavioral Science, 191, 103109. Diakses tanggal 18 Desember 2017 dari https://www.sciencedirect.com/science/article/pii/S1877042815027470.

Nurani, R.Z. (2017). Pengaruh Strategi Directed Listening Thinking Activity (DLTA) Berbantuan Media Audio Visual terhadap Kemampuan Menyimak Dongeng. Dwijacendekia Jurnal Riset Pedagogik, 1 (2), 79-86.

Nurgiyantoro, B. (2016). Penilaian Pembelajaran Bahasa Berbasis Kompetensi. Yogyakarta: BPFE-Yogyakarta.

Saddhono, K. \& Slamet. (2014). Pembelajaran Keterampilan Berbahasa Indonesia Teori dan Aplikasi. Yogyakarta: Graha Ilmu.

Tarigan, H.G. (2008). Menyimak Sebagai Suatu Keterampilan Berbahasa. Bandung: Penerbit Angkasa Bandung.

Wibowo, M.A. (2016). Penerapan Strategi Directed Listening Thinking Approach (DLTA) dalam Pembelajaran Keterampilan Menyimak pada Siswa Sekolah Dasar. Jurnal IImiah Guru "COPE" No. 01/Tahun XX/Mei 2016. Diakses tanggal $12 \quad$ Desember 2017 https://journal.uny.ac.id/index.php/cope/article/viewFile/10793/8122. 